\title{
Settlement Analysis of Road and Storage Areas Based on Organic Soil Surcharged by Ash - Slag Layer
}

\author{
Zygmunt Meyer ${ }^{1}$, Mariusz Kowalow ${ }^{2}$, Małgorzata Wróbel-Hen ${ }^{3}$ \\ ${ }^{1}$ Department of Geotechnical Engineering, Westpomeranian University of Technology, Szczecin, Poland \\ ${ }^{1,2,3}$ Geotechnical Consulting Office Sp. z o. o. Sp. k., Szczecin, Poland \\ E-mails: ${ }^{1}$ z.meyer@gco-consult.com (corresponding author); ${ }^{2}$ m.kowalow@gco-consult.com; \\ ${ }^{3}$ m.wrobel@gco-consult.com
}

\begin{abstract}
The outlet distance of large river, Odra in Poland is a place where large area of the terrain is made of peat. Those places are close to the river so the investors would like to use the area for industrial purpose having direct access to the waterways (cheap transport). One of the methods to reinforce the soft soil (peat) is consolidation. In the presented case the surcharging layer is made of fly ashes. The researches have been done at the Technical University of Szczecin that allow to formulate a mathematical description of peat consolidation in case when elasticity modulus of peat increases along with the consolidation process and the permeability coefficient for peat decreases. The method also allows to calculate the terminal settlement of the peat layer in a long time. The method was invented by Z. Meyer. The paper presents the method and the results of practical calculations in the case of peat from area of Szczecin Skolwin close to Odra River in Poland.
\end{abstract}

Keywords: Soil mechanics, soft soil, organic soil, consolidation, fly ashes.

Conference topic: Design experiences and theoretical solutions.

\section{Introduction}

In order to prepare certain areas for industrial activity soil reinforcement using so called consolidation of peat has been done. The areas are located directly on the Oder River in the district of Szczecin - Skolwin. The surcharge layer was made of fly ashes (Meyer 2014; Meyer et al. 2007).

The main advantage of the area located at the Odra river mouth is i.a. transshipment, production - warehousing function with access to navigable waters (Kowalow, Wróbel 2007; Meyer et al. 2007).

Geomorphologically, the considerd area is located on the western, part of swamped Odra river valley. The hydrographic system of artificial and natural channels, extending between the Western Oder, and Lake Dabie, is a very characteristic feature of this territory (Meyer et al. 2007).

On the considered area the surcharging layer made of fly ashes was executed. The thickness of ash - slagmix embankment varies from about 3 to $7 \mathrm{~m}$.

The ash fill layer is based on Holocene organic soil represented by peats and gyttja as well organic soil mixed with non cohesive soils layers (fine sands). The organic soil layers thickness before overloading according to geotechnical investigation varies from 3.8 to $8.4 \mathrm{~m}$.

Below the organic soils at a depth of approx.10.4 to $14.5 \mathrm{~m}$ b.g.l. (approx. [-]6.4 to [-]10.2 $\mathrm{m}$ a.s.l.) the fluvial sands were found. Fluvial sands are represented by the fine sands. In executed boreholes the noncohesive soil layer then has not been drilled trough.
On the basis of geotechnical study on the considered area the quaternary aquifer were found.

First aquifer is connected with the fill layer above the top bottom of organic soils. Free groundwater level is located at a depth of approx. 2.9-3.3 m b.g.l. ie. at the elevation approx. 1.25 to $1 \mathrm{~m}$ a.s.1.

Quaternary aquifer is formed of in non-cohesive fluvial layers and was drilled trough to the depth of about 10.4 to $14.5 \mathrm{~m}$ b.g.l.

The earth works according to the project were called "macroleveling". The job was made layer by layer of ashes. And the depth of a single layer was about $0.5 \mathrm{~m}$. The flay ashes were compacted by steam rollers.

The field works started in April 2011 and it was finished in September 2013. The thickness of the soil layers after consolidation they are shown in Figure 1. The boreholes were made by GCO.

From the historic sources it comes that the orginal level of the virgin peat was about $1 \mathrm{~m}$ a.s.l. So it means that the initial thicness of the peat was $10-15 \mathrm{~m}$. And now it is $6-9 \mathrm{~m}$.

Historical information is that after the II Wolrd War the area was initially surcharched with the waste layer about $1 \mathrm{~m}$.

The actually underground condition shows the geotechnical profile in Figure 1.

The subject of this paper is the analysis organic soils settlements caused by the under load of ash slag - mix. The finished load is caused by: operation load from the road and maneuver area and the weight of embankment made from fly ashes. 


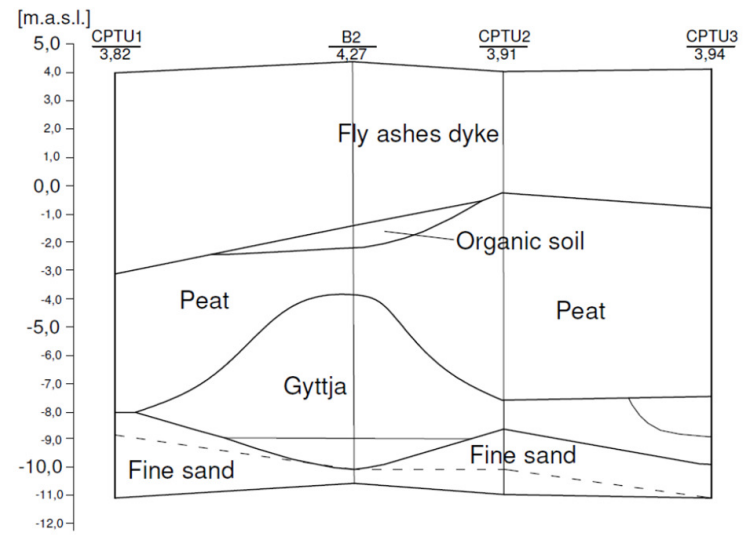

Fig. 1. Geological cross section

The practical calculations were referred to the areas devoted to the road building and the manoeuvre and storage areas (Meyer et al. 2008, Meyer et al. 2007; Kowalow, Wróbel 2007).

\section{Settlements calculations}

Settlements calculation was proceeded for two cases taking into account the variability of the geotechnical conditions (Meyer 2012, 2014; Wiłun 2000).

Case I was assumed as the foundation based on ash - slag - mix layer with a thickness of approx. $7 \mathrm{~m}$ and the below organic soil layer with a thickness of approx. $5 \mathrm{~m}$.

Schematic geotechnical conditions of the case I is shown in Figure 2.

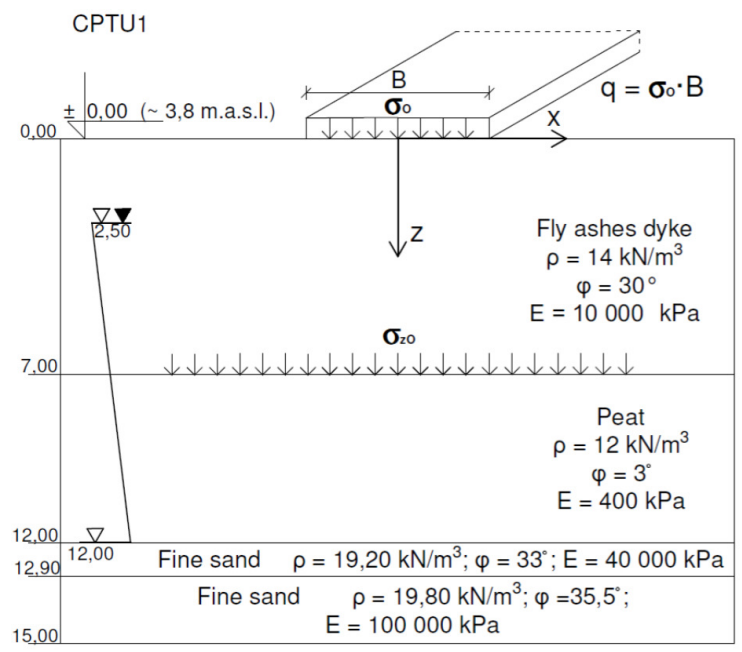

Fig. 2. The scheme of the soil profile - Alternative I (according to CPTU1)

In the case II the thickness of ash - slag - mix layer is approx. $4 \mathrm{~m}$, while the thickness of the peats layer was approx. $8.5 \mathrm{~m}$. The schematic layout of the case II is shown in Figure 3.

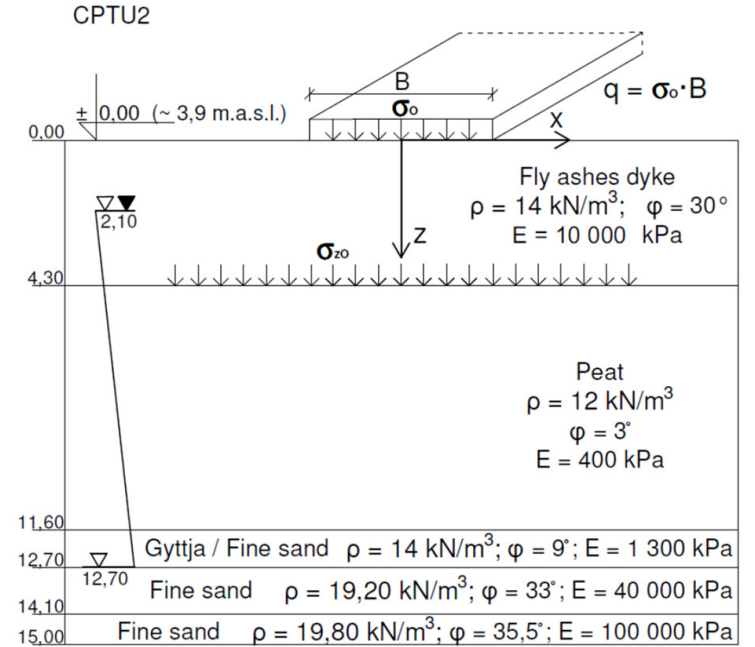

Fig. 3. The scheme of the soil profileAlternative II (according to CPTU2)

Settlements calculation of organic soil (peats, gytja) caused by mound which is made of fly ashes mixture

The settlement calculation of organic soil (peats, gyttjas) caused by a strip foundation (road) was made according to the Boussinesq equation which give the distribution of vertical stress beneath the embankment. The equation has form (1), (Meyer 2012, 2014; Wiłun 2000):

$$
\sigma_{z}=\frac{2}{\pi} \frac{q z^{3}}{\left(\begin{array}{c}
2 \\
x+z^{2}
\end{array}\right)^{2}},
$$

where:

$q$ - the load charge per unit length $[\mathrm{kN} / \mathrm{m}], x, z$ - coordinates of chosen system, $\sigma_{z}-$ stresses in the soil according to Boussinesq equation [kN/m2].

In these case:

$$
q=\sigma_{0} B
$$

where:

$B$ - the width of the road $[\mathrm{m}], \sigma_{0}-$ load which is applied along the road $[\mathrm{kPa}]$.

The stress along the road at the top of organic soils it is equation no. 3 . In this equation denote the depths of dyke layer and then beneath there are organic soils:

$$
\sigma_{z 0}=\frac{2}{\pi} \sigma_{0} \frac{B}{h_{0}},
$$

where:

$h_{0}-$ thickness of fill layer between road foundation level and top of organic soil [m].

The calculation was proceeded taking into account the parameters which are shown in Figures 2 and 3.

The settlement of the organic soil due to the load of this embankment it can be also calculated directly from equation. And so we have: 


$$
s=H_{0} \frac{\sigma_{z 0}}{M_{0}},
$$

where:

$H_{0}$ - thickness of organic soil [m],

$M_{0}$ - elasticity modulus of organic soil [MPa].

After the calculation it comes that the settlement it is equal $97 \mathrm{~cm}$ to alternative I and $39 \mathrm{~cm}$ to alternative II.

\section{The settlement calculation of the organic soil taking into account the changes of the elasticity modulus due to consolidation}

When calculating settlements for the organic soil due to the load coming from the road we must take into a count the consolidation of the organic soil. The consolidation is due to the load from the embankment, which is made by the mixture of fly ashes (Meyer 2012; Kowalów 1988; Meyer, Kowalów 1987).

As the consolidation results it is also that the elasticity modulus is increasing. The elasticity modulus of the organic soil after consolidation may be calculated from Equation (5):

$$
M_{(s)}=M_{0}\left[1+\frac{\kappa-1}{n_{0}} \cdot \frac{\sigma}{M_{0}}\right]^{\frac{\kappa}{\kappa-1}} .
$$

In these formula $M_{0}$ it is elasticity modulus before the consolidation [MPa], $\mathrm{n}_{0}$ is porosity for the unload peat and $\kappa$ is dimensionless parameter.

According to the elasticity modulus given by Equation (5) we can calculate the settlement. The settlement is given by the Equation (6):

$$
s=n_{0} h_{0}\left[1-\left(1+\frac{\kappa-1}{h_{0}} \cdot \frac{\sigma_{0}}{M_{0}}\right)^{\frac{-1}{\kappa-1}}\right] \text {. }
$$

Parameters $n_{0}$ and $\kappa$ can be obtain from following relationships:

$$
\begin{gathered}
n_{0}=1-\frac{1}{12} \sigma_{k o n}^{1 / 3} ; \\
\kappa=2,2 \sigma_{k o n}^{-1 / 18} .
\end{gathered}
$$

In this equation:

$\sigma_{k o n}$ - denotes the stress which is applied to the surface of peat due to the mound layer made of fly ashes [kPa].

There are formulated upon field measurements, so there are empirical.

Settlement in general case consists of the settlements of fly ashes and peats settlement.

The settlement of the fly ashes layer it can be calculated from Equation (9):

$$
s_{1}=\frac{\sigma_{0}}{E_{p}} z_{0} .
$$

In this equation:

$E_{p}$ - elasticity modulus of fly ashes layer [MPa], and

$z_{0}-$ active zone depth [m].
The settlement of peat upon road load $s_{2}$ can be calculated from Equation (6). Then we have:

$$
s=s_{1}+s_{2} \text {. }
$$

To calculate the extent so called active zone depths under the road was used the following Equation (11):

$$
z_{0}=1,5 B \sqrt{\frac{\sigma_{0}}{\gamma B}} .
$$

The total settlement of the road build upon the mound layer based on soft organic soils may be calculated from Equation (12):

$$
s=\sigma_{0}\left(\frac{z_{0}}{E_{p}}+\frac{H_{0}}{M_{(s)}}\right),
$$

where:

$E_{p}$ - elasticity modulus of fly ashes [MPa], and $M_{(s)}$ - denotes elasticity modulus of consolidated peat [MPa].

We can than calculate practically how big the settlement is. For calculation it was taken $\sigma 0$ (it means the load coming from the road), $33 \mathrm{kPa}$ - in Poland that is the road of the 2 class. In alternative I, if we assume the initial values of soil parameters which was taken previously the settlement is equal to $86 \mathrm{~cm}$.

If we assume that peat settlement, which is beneath the mound layer, ends when construction works are finished, then the additional settlements which is due to additional load it is only $27 \mathrm{~cm}$. And that must be taken to account when we would like to build a road on peat using the mound layer which is made of fly ashes.

\section{Settlements calculation of maneuver area which is based upon mound layer made of fly ashes}

To calculate the settlement of the maneuver area mathematical model of this phenomenon was taken exactly how it is for the large foundation plates (Meyer 2014; Meyer 2012):

$$
s=\frac{\sigma_{0}}{E_{p}} z_{0} .
$$

The active zone depths can be calculated from Equation (14).

$$
z_{0}=\frac{\alpha}{\ln \left(\frac{E_{p}}{\sigma_{0}}\right)} \cdot \frac{\sigma_{0}}{\gamma}
$$

where:

$\sigma_{0}-$ the load from the road $[\mathrm{kPa}]$,

$\gamma-$ specific density of soil $\left[\mathrm{kN} / \mathrm{m}^{3}\right]$.

In Equation (14) is the $\alpha$ dimensionless parameter which is calculated from the Equation (15).

$$
\alpha=\frac{1}{2 \tan \varphi},
$$

where:

$\varphi$-internal friction angle of fly ashes layer $\left[{ }^{\circ}\right]$. 
For practical calculation the load which is coming from the road again was taken $33 \mathrm{kPa}$ and the calculation was proceeded for the alternative I. Assuming the same initial values for the soil as before, the settlement is then $86 \mathrm{~cm}$.

\section{Conclusions}

The paper presents the analytical method for settlements calculation of soft organic soils which are consolidated using charging layer made of fly ashes. In such a case it has been foreseen that the road will be build and maneuver area will be constructed. In case no1 and no 2 it has been assumed that the load coming from the road and the maneuver area it will be $33 \mathrm{kPa}$.

The presented calculations they consider three different cases. Case no 1 that is the settlement of the road mound layer, which is placed upon consolidated peat. In these case is the settlement is $59 \mathrm{~cm}$.

The calculation shows, that the biggest part of settlements that is a settlement of peat. In practical case we can assume that the settlement inside the charging layer which is made of fly ashes is so small that can be neglected.

For more precise calculations we should assume model which is taking into account the parameters of peat which are varying due to settlement. The researches that have been done on these subject they show that when the consolidation follows it is accompanied by settlement and it is accompanied by increasing elasticity modulus. That is the reason that the total settlement is smaller than in the case when the elasticity modulus is constant. All those equations are given in this paper.

Upon these assumptions it cams that, the settlement of the soft soil (peat) is $86 \mathrm{~cm}$. It is coming from the mound layer and we shell stress that the thickness of the soft soils is quite big, $7 \mathrm{~m}$.

If we assume that the settlement of the peat due to mound layer ends dyke when the site construction is finish than additional settlements due to load from the road is only $27 \mathrm{~cm}$. It is still quite a big settlement but we can consider if we can accept it.

Standard method which allowed to calculate consolidation for organic soils presented in the literature, they assume the model constant of the elasticity modules. And so, the settlement is bigger than in case which is presented in this paper, when the elasticity modulus increases according to the settlement.

Research that have been done on these subject they imply that if we include increasing elasticity modulus we still do not a have very high stiffness of the soft soils. So, we should state, that upon consolidated organic soil we can based only certain buildings which are not very sensitive for the settlements and specially for the settlement differences.

\section{References}

Kowalów, M.; Wróbel, M. 2007. Budowa lini kolejowej na gruntach organicznych w Porcie Szczecińskim, $X V$ Seminarium Naukowe z cyklu Regionalne Problemy Ochrony Środowiska, 6-7 lipca 2007, Szczecin-Tuczno, Poland, 73-76.

Kowalów, M. 1988. Empiryczny model konsolidacji torfów w warunkach długiego czasu konsolidacji, Prace Naukowe Politechniki Szczecińskiej 379(4): 69-77.

Meyer, Z. 2014. Czy możemy posadowić obiekty budowlane bezpośrednio na torfach? Księga Jubileuszowa z okazji 70-lecia urodzin i 45 - lecia pracy naukowej Profesora Zygmunta Meyera, Westpomeranian University of Technology.

Meyer, Z. 2012. Obliczenia inżynierskie osiadania fundamentów. ZAPOL.

Meyer, Z.; Kowalów, M.; Bednarek, R. 2007. Zmiany sposobu wzmacniania gruntów słabych na Ostrowie Grabowskim w oparciu o badania konsolidacji torfów, XXIII Konferencja Naukowo-Techniczna "Awarie budowlane" 23-26 maja 2007, Szczecin-Międzyzdroje, Poland, 453458.

Meyer, Z.; Kowalów, M.; Bednarek, R. 2008. Wpływ zmiany parametrów gruntowych na szybkość konsolidacji torfu, XVI Seminarium naukowe z cyklu Regionalne Problemy Ochrony Środowiska, 12-14 czerwca 2008, Szczecin Praga, Poland, 97-103.

Meyer, Z.; Kowalów, M. 1987. Funkcja czasu w empirycznym modelu konsolidacji torfów, Prace Naukowe Politechniki Szczecińskiej 357, Geotechnika III: 69-94.

Wiłun, Z. 2000. Zarys geotechniki. WłiK. 